\title{
Woordeboek vir Tuinboukunde (Ingeslote Plantname)
}

\author{
L.C. Holtzhausen en L.A. Genis
}

Die vak Tuinboukunde kan gedefinieer word as die wetenskap en/of kuns wat hom bemoei met die kweek van vrugte, groente, blomme, sierstruike en -bome en die gepaardgaande bestuur daarvan in ' $n$ tuin, boord of landgoed. Die tuinboubedryf dra tans meer as drie miljard rand tot die ekonomie van die land by.

Die vak steun baie sterk op en het as pilare die aanverwante dissiplines Plantanatomie, Plantbiochemie en Plantfisiologie. Die vakgebied toon ook raakpunte met verskeie ander vakgebiede. Die toekomstige gebruiker van die Woordeboek kan dus verwag om terme wat tuishoort by Genetika, Plantsiektekunde, Akkerbou, Grondkunde, Landbouingenieurswese, Landskapsontwerp ens., hier aan te tref. Met die opstel van die Woordeboek is gepoog om dié terme wat die hoogste gebruiksfrekwensie in die verskeie subdissiplines toon, op te neem. Benewens die algemene tuinboukundeterme bevat die Woordeboek ook 'n onderafdeling waarin die taksonomiese benamings asook die Afrikaanse en Engelse volksname van plante vervat word. Met laasgenoemde was die hulp van mev. Elize Buitendag en mnr. D.G.C. du Plessis van onskatbare waarde.

Sedert die eerste lys tuinbouterme - wat baie verouderd en reeds etlike jare uit druk is - in 1971 verskyn het, het die status van Tuinboukunde as vakgebied met rasse skrede toegeneem en die behoefte aan 'n volwaardige Tuinboukundewoordeboek het sterk op die voorgrond getree. Hierdie behoefte is deur die Nasionale Vakterminologiediens (NVD) van die Departement van Nasionale Opvoeding geïdentifiseer, veral op grond van die toename in terminologienavrae op tuinboukundige gebied wat die NVD daagliks moet hanteer. Dit het tot gevolg gehad dat die projek om 'n woordeboek vir tuinboukunde en plantname, wat tred hou met die jongste ontwikkelings, van stapel gestuur is. Die Woordeboek is tans reeds by die staatsdrukker en die verwagte publikasiedatum sal voor einde Februarie 1991 wees.

Konseplyste van tuinboukundeterme is landwyd aan instansies soos universiteite, technikons en navorsingsinstitute vir kommentaar versprei en belangstellendes is om samewerking gevra. Dit het alles daartoe gelei dat 'n Redaksiekomitee vir Tuinboukunde in Augustus 1987 in die lewe geroep is om die terme in komitee te behandel. Die komi- tee bestaan uit:

Voorsitter: Prof. L.C. Holtzhausen, Hoof, Dept. Tuinboukunde, Universiteit van Pretoria, Assessorlid S.A. Akademie.

Lede: Mnr. D.G.C. du Plessis, Senior lektor, Plantkunde, Technikon Pretoria. Dr. D.I. Ferreira, Adjunkdirekteur, Navorsingsentrum vir Plantbiotegnologie, Dept. Landbou-ontwikkeling, Lid S.A. Akademie. Dr. P.F. Nortjé, Assistentdirekteur, Aartappelseksie, Dept. Landbou-ontwikkeling.

Sekretariaat: Mev. L.A. Genis, Hooftaalpraktisyn, Nasionale Vakterminologiediens. Mev. E.C. Nothnagel, Taalpraktisyn, Nasionale Vakterminologiediens.

Bo en behalwe die klaarblyklike teikengroep van student, dosent en navorser in die tuinboukunde, vertaler en joernalis, word dit ook ten doel gestel om die gewone tuinmaakentoesias leiding te gee op die gebied van tuinboukundeterminologie. Die uitgebreide lys plantname kan van onskatbare waarde wees vir tuinier en kwekeryeienaar.

Vergaderings van die Redaksiekomitee was uiters leersaam en stimulerend en daar is dikwels hewig gestoei met die benoeming van sake en begrippe waarvoor daar nog geen - of geen aanvaarbare - Afrikaanse ekwivalente bestaan het nie. So het die Komitee na veel geredekawel besluit dat die Afrikaanse ekwivalent van die Engelse term fertigation besproeiingsvoeding moet wees. Vapour drift het newelwegdrywing, newelswewing of dampdrywing en skirting het soomsnoei geword, om maar enkele voorbeelde te noem.

Die saamstel van woordeboeke is 'n deurlopende taak en die vaslegging van data word slegs tydelik onderbreek om die data wat reeds op rekenaar bekikbaar is aan die gemeenskap beskikbaar te stel. Die hersiening van die Woordeboek vir Tuinboukunde en Plantname sal reeds weer in volle gang wees teen die tyd dat dit op die boekhandelaar se rak verskyn. Die onus sal by die gebruiker berus om die Woordeboek korrek en by te hou deur enige kommentaar oor die korrektheid of volledigheid daarvan aan prof. L.C. Holtzhausen, Departement Tuinboukunde, Universiteit van Pretoria of aan mev. L.A. Genis, Nasionale Vakterminologiediens, Privaat sak X122, te rig.

\section{Biotegnologieterme}

\author{
D.I. Ferreira \\ Navorsingsentrum vir Plantbiotegnologie, Privaat sak X293, Pretoria 0001
}

Biotegnologie is inderwaarheid 'n "ou" wetenskap, omdat die mens duisende jare reeds brood bak en wyn en bier brou. Sedert Watson en Crick se ontdekking van die dubbelheliksstruktuur van DNS in 1956 het ontwikkelings op hier- 
die gebied egter snel toegeneem. Met die kommersialisering van biotegnologie en die opwindende deurbrake in molekulêre biologie het talle nuwe terme in geskrifte begin verskyn. Vir die Afrikaanssprekende wetenskaplike skep dit die geleentheid om deel te neem aan die ontwikkeling van Afrikaans. Ongelukkig bestaan die geneigdheid egter om die Afrikaanse terme so na as moontlik aan die internasionale terme te hou, soos amplifikasie vir amplification. Dit het die ooglopende voordeel dat verwarrings beperk kan word, maar dikwels is die vertalings omslagtig (bv. genoombiblioteek vir genomic library, in plaas van genoteek) en word die werklike en korrekte betekenis nie altyd weerspieël nie (bv. haelgeweerklonering vir shotgun cloning, waar lukraak-klonering beskryfwender is). 'n Sinvolle oplossing vir die probleem is om sowel die vertaalde term as 'n egte Afrikaanse term te erken en dan as wisselvorme te gebruik. Sekere terme word reeds as internasionale terme erken en gebruik. Daar bestaan egter meningsverskil oor die gebruik. Afkortings soos DNA (deoksiribonukleiensuur) en RNA (ribonukleïensuur) word reeds algemeen in die vaktaal gebruik. Volgens die Afrikaanse Woordelys en Spelreëls ${ }^{1}$ word slegs DNS en RNS erken. $\mathrm{Na}$ my mening het dit tyd geword dat dié besluit hersien word. Boeke en ander publikasies oor Biotegnologie in Afrikaans is so skaars soos hoendertande. Na my wete is daar tans slegs een Afrikaanse publikasie wat 'n lys met terme bevat en die handel oor "Terme in Molekulêre Mikrobiologie". Verskeie biotegnologieterme is egter in die Tuinbouwoordeboek wat tans ter perse is, opgeneem.

Dit is onmoontlik om binne die bestek van 'n rubriek soos hierdie al die betrokke terme te lys. Gevolglik sal daar gepoog word om enkele algemene en interessante terme aan te bied. Dit moet beklemtoon word dat hierdie terme nie as amptelike vertalings beskou moet word nie en dat kommentaar dus verwelkom sal word.

\section{GESELEKTEERDE BIOTEGNOLOGIETERME}

Adenien - Adenine. Purienbasis wat in nukleïensure aangetref word.

Alleel - Allele. Een van 'n reeks alternatiewe vorme van 'n geen.

Amplifikasie - Amplification. Die proses waartydens die kopié van 'n spesifieke geen of chromosomale volgorde vermeerder word. Sinoniem: Versterker

Androgenese - Androgenesis. Die regenerasie van plante uit stuifmeel.

Annelering - Annealing. Die reassosiasie tussen die komplementêre nukleïensuurenkeldrade van 'n gedenatureerde dubbeldraad om weer die oorspronklike dubbeldraadnukleïensuur te vorm.

Antisin - Antisense. Ketting van DNS wat dieselfde basisopeenvolging as die mRNS van die funksionele geen het.

Attenueerder - Attenuator. 'n Regulerende nukleotiedvolgorde in die nie-koderingsgedeelte van 'n mRNSmolekuul (naby aan die 5'kant) wat betrokke kan wees by transkripsieterminasie.

Beëindigingskodon - Stop codon. Kodon wat die beëindiging van vertaling (translasie) spesifiseer. Sinoniem: Stopkodon.

Beperkingsendonuklease - Restriction endonuclease. 'n Endonuklease wat spesifieke kort basisvolgordes van 'n ongemetileerde DNS herken en die dubbeldraad by die herkenningsetel self of op ' $n$ bepaalde afstand daarvandaan sny. Sinoniem: Restriksie-endonuklease.

Biotegnologie - Biotechnology. Tegnologie wat die benutting van organismes (of dele van organismes) in biologiese prosesse behels, met die oog op die ontwikkeling van bepaalde produkte. Dit word gebruik ten opsigte van weefselkukture en rekombinante-DNS tegnologie.

cDNS (Komplementêre DNS) - cDNA (Complementary $D N A)$. Enkeldraad-DNS wat op 'n enkeldraad-RNStemplaat gesintetiseer is deur ' $n$ in vitro trutranskriptasereaksie.

cDNS-klonering - $c D N A$ cloning. Die tegniek waartydens 'n RNS-templaat (gewoonlik mRNS) eers in 'n enkeldraad-cDNS omgeskakel word in 'n trutranskriptasereaksie en later as dubbeldraad-cDNS (dcDNS) ingelas word in 'n geskikte kloneringsvektor vir amplifisering.

Chromosoomwandeling - Chromosome walking. 'n Tegniek wat gebruik word om die liniêre volgorde van gene of nukleotiedvolgordes op 'n chromosoom te identifiseer deur van die isolasie en identifikasie van gekloneerde DNS-fragmente waarvan die eindgebiede oorvleuel, gebruik te maak.

DNS-klonering - DNA cloning. Die proses waartydens die genetiese materiaal van een organisme in 'n DNSmolekuul-vorm gekombineer word met die DNS van 'n ander geskikte gasheerorganisme, sodat dit as deel van die gasheergenoom kan vermenigvuldig en indien nodig, weer uit die gasheer geïsoleer kan word.

DNS-transformasie - DNA transformation. Genetiese wysiging waardeur die skenker se genetiese materiaal opbreek en as vry DNS deur die ontvanger opgeneem word.

DNS-vingerafdrukke - DNA fingerprinting. 'n Tegniek met behulp waarvan 'n restriksiefragment-lengte-polimorfisme-patroon gekry word wat uniek is aan ' $n$ individu deur gebruik te maak van 'n varieerbare tandemherhaalvolgorde wat by verskillende lokusse op die chromosoom voorkom.

Ekspressievektor - Expression vector. 'n Kloneringsvektor wat so ontwerp is dat 'n vreemde geen wat in die vektor ingelas word, in die gasheersel van die vektor uitgedruk kan word. Sinoniem: Uitdrukkingsvektor.

Elektroporasie - Electroporation. 'n Metode waarvolgens selle aan 'n hoë elektriese spanning vir kort periodes blootgestel word, met die doel om die direkte opname van toegevoegde DNS deur die selmembraan te bevorder.

Embrioredding - Embryo rescue. Die kweek van embrio's (meesal van plante) op 'n kunsmatige voedingsmedium onder steriele toestande om aborsie te voorkom.

Entmerking - End labeling. 'n Tegniek wat die toevoeging van radioaktiewe groepe aan die 5- of 3-ent van 'n nukleïensuurketting beskryf.

Geenekspressie - Gene expression. Al die verskillende stappe wat betrokke is by die uitdrukking van die genetiese inligting van 'n geen in die vorm van 'n funksionele proteïen. Sinoniem: Geenuitdrukking.

Geenkartering - Gene mapping. Die bepaling van die relatiewe posisies van verskillende gene op 'n DNS- 
molekuul.

Geenklonering - Gene cloning. Die invoeging van 'n DNS-fragment wat die inligting bevat vir die sintese van 'n funksionele polipeptied of RNS-molekuul in ' $n$ kloneringsvektor en die daaropvolgende vermeerdering van die rekombinante DNS in 'n gasheer.

Gel-elektroforese - Gel electrophoresis. Elektroforese wat in 'n bepaalde jelmatriks uitgevoer word sodat molekules met 'n gelyke lading op grond van molekulêre grootte geskei kan word.

Genetiese manipulasie - Genetic engineering. Die konstruksie van rekombinante-DNS-molekules deur die samevoeging van gene in nuwe kombinasies. Sinoniem: Genetiese boukunde.

Genoteek - Genomic library. 'n Versameling van gekloneerde DNS-fragmente waarin die volle genoom van die organisme verteenwoordig is. Sinoniem: Genoombank, Genoombiblioteek.

Hibridisasie - Hybridisation. Die vorming van 'n dubbeldraadnukleïensuurhibried na komplementêre basisparing tussen enkeldraadnukleïensure (RNS en DNS) van verskillende oorspronge.

In situ-hibridisasie - In situ hybridisation. Die renaturasie van 'n radioaktiefgemerkte nukleiensuurpeiler met komplementêre gedenatureerde DNS of RNS in hulle oorspronklike posisies binne-in 'n gefikseerde sel.

In vitro-mutagenese - In vitro mutagenesis. Die tegnologie waardeur 'n spesifieke basispaarmodifikasie (mutasie) by ' $n$ voorafgeïdentifiseerde posisie in ' $n$ DNS-molekuul bewerkstellig kan word.

In vitro-verpakking - In vitro packaging. Die invoeging van nuklejensuur in viruspartikels deur die in vitrosamevoeging van viruskapsiedproteïene en virus-DNS.

Invoegingsinaktivering - Insertional inactivation. Die kloneringstrategie waardeur die invoeging van vreemde DNS in 'n vektor tot gevolg het dat een van die vektorgedraagde merkergene geïnaktiveer word.

Kallus - Callus. 'n Groep ongedifferensieerde plantselle wat in sommige spesies geinduseer kan word om plante te vorm

Kapsied - Capsid. Die proteïendop waarmee die genetiese materiaal (RNS of DNS) van 'n virus of bakteriofaag omsluit word. Sinoniem: Kapsel.

Kaset - Casette. 'n Rekombinante DNS-fragment wat by sekere tipes ekspressievektore voorkom. Dit bestaan gewoonlik uit 'n promotor, 'n ribosoombindingsplek en unieke beperkingsensiemsnyplek(ke).

Keep - Nick. 'n Breuk in die fosfodiesterbinding van twee naasliggende nukleotiede in een draad van 'n dubbeldraadnukleïensuurketting.

Keeptranslasie - Nick translation. Die reaksie waarin dubbeldraad-DNS uniform met 'n radio-isotoop gemerk kan word in 'n in vitro-reaksie waartydens 'n eksonuklease, nukleotiede in 'n 5'--> 3-rigting van die DNS verwyder vanaf willekeurig verspreide kepe in die DNS en hierdie gapings word weer opgevul deur radioisotoopgemerkte nukleotiede met behulp van DNSpolimerase in te bou. Sinoniem: Keepverplasing, keepvertaling.

Kleefent - Sticky end. Die ent van 'n dubbeldraad-DNSmolekuul met 'n enkeldraad-DNS-verlengstuk.

Kloon - Clone. 'n Groep van selle of organismes wat gene- ties identies is en vanuit 'n enkele ouersel of organisme ontwikkel het.

Kodeerstring - Coding strand. Die enkeldraad van dubbeldraad-DNS of -RNS wat dien as templaat vir die transkripsie van 'n bepaalde geen in 'n komplementêre mRNS. Sinoniem: Sinstring.

Komplementêre DNS (cDNS) - Complementary DNA. 'n DNS-molekuul wat gevorm word deur transkripsie vanaf 'n RNS-templaat met behulp van 'n trutranskriptase-ensiem.

Konstitutiewe promotor - Constitutive promotor. ' $n$ Promotor wat die konstitutiewe sintese van 'n bepaalde mRNS reguleer.

Koppelstuk - Linker. 'n Kort sinteties vervaardigde dubbeldraad-DNS-oligonukleotied met 'n nukleotiedherkenningsvolgorde met spesifisiteit vir een of meer beperkingsensieme. Sinoniem: Lasstuk.

Kweekmedium - Culture medium. Enige voedingsisteem wat vir die kunsmatige kweking van bakterieë of ander selle gebruik word - gewoonlik 'n komplekse mengsel van organiese en anorganiese stowwe. Sinoniem: Kultuurmedium.

Lukraak-klonering - Shotgun cloning. 'n Kloneringstrategie waartydens 'n mengsel van alle moontlike DNS-restriksiefragmente van 'n groter DNS-molekuul in 'n kloneringsvektor ingelas word, sodat 'n groot verskeidenheid verskillende rekombinante-DNS-molekules verkry word. Sinoniem: Haelgeweerklonering.

Mikro-inspuiting - Micro injection. 'n Tegniek waarvolgens DNS meganies in 'n sel ingevoeg kan word deur dit direk in die selkern in te spuit.

Noordelike-kladtegniek - Northern blot transfer. 'n Tegniek waartydens RNS vanaf agarose- of poliakrielamiedjels oorgedra en gebind word na 'n membraan of papier. Sinoniem: Noordkladtegniek.

Nukleïensuurpeiler - Nucleic acid probe. 'n Gemerkte nukleïensuur wat gebruik kan word vir die identifikasie van komplementêre of homoloë nukleïensuurmolekules. Hibriede tussen 'n peiler en 'n teikennukleïensuur word gestabiliseer deur basisparing tussen komplementêre basisse van die twee nukleiensure.

Omgekeerde herhaling - Inverted repeat. Twee identiese nukleotiedvolgordes met teenoorgestelde orientasie in 'n bepaalde DNS-molekuul.

Omkering - Inversion. Verandering van 'n DNS-molekuul deur 'n fragment te verwyder, sy orientasie om te keer en dit terug op sy plek te plaas.

Onkogeen - Oncogene. 'n Geen wat tumorvorming kan inisieer.

Ontwapende Ti-plasmied - Disarmed Ti-plasmid. 'n Tiplasmied waarvan al die transformasie (T)-DNS gene verwyder is sodat dit nie langer plantselle in kankerselle kan transformeer nie.

Operateur - Operator. 'n Reguleringsgebied in DNS wat met 'n spesifieke repressor- of inisieerderproteïen kan verbind en die transkripsie van aangrensende gene beheer. Sinoniem: Operator.

Passtuk - Adaptor. 'n Kunsmatig vervaardigde dubbeldraad-DNS-oligonukleotied met 'n beperkingsensiem-spesifieke kleefent. Dit word gebruik om 'n spesifieke kleefent aan 'n stompent-nukleiensuurfragment te las. 
Pendelvektor - Shuttle vector. 'n Plasmiedvektor wat oor twee verskillende oorspronge van replikasie beskik waardeur dit in verskillende gashere kan repliseer.

Poli(A)stert - Poli(A)tail. 'n Polimeriese volgorde van adenienbasisse wat natuurlik aan die 3'punt van eukariotiese mRNS-molekules voorkom. Hierdie stert word tydens mRNS-prossesering aan die primêre RNStranskrip gelas.

Poli-adenilering - Poliadenylation. Die reaksie waartydens 'n volgorde van adenienbasisse aan die 3'-kant van 'n nukleiensuur toegevoeg word.

Pribnow-kassie - Pribnow box. 'n DNS-reguleringselement met die konsensusvolgorde TATAAT wat omtrent 10 basispare stroomop van die beginpunt vir geenekspressie geleë is. Dit is deel van die promotor en belangrik vir die binding van RNS-polimerase. Sinoniem: Pribnow-hokkie.

Promotor - Promoter. Die DNS-volgordes wat dien as 'n positiewe sein vir die transkripsie van 'n bepaalde geen. RNS-polimerase bind direk aan sekere van die volgordes.

Protoplas - Protoplast. 'n Sel waarvan die selwand volledig verwyder is. Sinoniem: Protoplast.

Protoplasfusie - Protoplast fusion. Die samesmelting van twee of meer protoplaste waardeur 'n sel gevorm word wat die kernmateriaal van beide donateurs bevat. Sinoniem: Protoplassamesmelting, protoplasversmelting.

Rekombinante DNS (rDNS)-molekuul - Recombinant DNA ( $r D N A)$ molecule. 'n DNS-molekuul wat in vitro saamgestel is deur stukke DNS met beperkingsensieme te sny en met ligases aan mekaar te las sodat nuwe kombinasies geskep kan word.

Restriksiefragment-lengte-polimorfisme (RFLP) - Restriction fragment length polimorfism (RFLP). Dit is 'n DNS-polimorfisme wat herken word deur enige verandering in die lengte van die fragmente wat gekry word wanneer die DNS met ' $n$ bepaalde beperkingsensiem gesny word.

Selektiewe merker - Selective marker. 'n Vektorgedraagde geen wat 'n herkenbare fenotipiese eienskap aan sy getransformeerde gasheersel oordra.

Selsuspensiekultuur - Cell suspension culture. Die kweek van plant- of dierselle in 'n vloeibare, kunsmatige groeimedium.

Selvrye translasiesisteem - Cell free translation system. 'n Selekstrak wat al die komponente bevat wat vir proteiensintese nodig is en wat in staat is om mRNS-molekules te vertaal.

Sinstring - Sense strand. Die DNS-draad wat dien as templaat vir die transkripsie van 'n bepaalde geen. Sinoniem: Kodeerstring.

Southern-kladtegniek - Southern blot transfer. 'n Tegniek waarmee gedenatureerde DNS vanaf 'n agarose akrielamiedjel oorgedra word na en gebind word aan 'n membraan waar dit gehibridiseer kan word met gemerkte nukleïensuurpeilers.

Splitslas - Splicing. Die verwydering van introns en die aanmekaarlas van eksons van 'n primêre transkripsieproduk.
Stompent - Blunt end. Die punt van 'n dubbeldraad-DNSmolekuul wat daardeur gekenmerk word dat al twee komplementêre drade by dieselfde nukleotiedposisie eindig sonder enige enkeldraad kleefente.

Stompentligering - Blunt end ligation. 'n Reaksie waarin twee dubbeldraad-DNS-fragmente direk met hulle stompente aan mekaar gelas word deur middel van fosfodiesterbindings.

T-DNS - T-DNA. Die deel van 'n Ti-plasmied wat na die plant-DNS oorgedra word.

Templaat - Template. 'n Enkeldraadnukleïensuurketting of die draad van 'n dubbeldraadnukleïensuurketting wat gebruik word as bloudruk vir die sintese van 'n komplementêre nukleiensuur. Sinoniem: Sjabloon.

Termineerder - Terminator. Die kort nukleotiedvolgorde wat dien as die sein vir die beëindiging van transkripsie. Sinoniem: Stopsetter.

Ti-plasmied - Ti-plasmid. Tumorinduserende plasmied wat dikwels vir kroongalgewasinduksie verantwoordelik is.

Transformasie - Transformation. Verandering in die genetiese samestelling van 'n organisme deur die invoeging van vreemde DNS.

Transgeniese organisme - Transgenic organism. 'n Organisme wat ontwikkel is deur die eksperimentele invoeging van DNS in die genoom van die organisme.

Transkripsievektor - Transcription vector. 'n Vektor wat so ontwerp is dat DNS wat daarby ingelas word, in die teenwoordigheid van 'n RNS-polimerase getranskribeer word.

Translasie - Translation. Proses waardeur die genetiese informasie wat in ' $n$ mRNS-molekuul aanwesig is, die volgorde van die spesifieke aminosure in 'n polipeptiedketting tydens proteiensintese spesifiseer. Sinoniem: Vertaling.

Transposon - Transposon. 'n DNS-segment wat rond kan beweeg en op verskeie plekke in die DNS van bakterieë ingevoeg kan word.

Voorvoerder - Primer. 'n Kort enkeldraadoligonukleotied wat deur basisparing aan 'n komplementêre enkeldraadDNS-templaat kan bind. Hierdeur word 'n nukleotied met 'n vry 3'hidroksielgroep verskaf, wat die beginpunt is vir die sintese van 'n komplementêre DNS-draad met behulp van 'n polimerase-ensiem. Sinoniem: Inleier, ontsteker.

Weefselkultuur - Tissue culture. Die in vitro-kweking van selle, weefsels of organe op 'n kunsmatige voedingsmedium onder steriele toestande.

\section{LITERATUURVERWYSINGS}

I. Afrikaanse Woordelys en Spelrë̈ls (1991). Agtste verbeterde uitgawe, S.A. Akademie vir Wetenskap en Kuns, pp. 123, 343 en 368.

2. Prctorius I.S. (1989). Rekombinante DNA-leghologie aan die hand van gis as eksperimentele model (Universiteitsuitgewers en Boekhandelaars (Edms.) Bpk. Stellenbosch). 